Abstract-A total of 69 specimens of Fedorov's lumpsucker (Eumicrotremus fedorovi) caught on the continental shelf and slope of Simushir Island in the northwest Pacific Ocean were dissected and studied for stomach contents. The Fedorov's lumpsucker was found to feed mainly on the young of fish species, including the walleye pollock (Gadus chalcogrammus), northern lampfish (Stenobrachius leucopsarus), and northern smoothtongue (Leuroglossus schmidti), crustaceans, such as Themisto pacifica, Primno macropa, calanoids, gammarids, mysids, and caprellids, and squid. Histological analyses of ovaries revealed iteroparity, determinate fecundity, group-synchronous ovarian development, and total spawning. Testes were of an unrestricted lobular type. Chorion and thick zona radiata of Fedorov's lumpsucker correspond to the condition of eggs in specimens of other fish species that release demersal eggs. Absolute fecundity values of Fedorov's lumpsucker in our study were significantly less than those that have been reported for other species of Cyclopteridae. The results of this study provide the first data on this little known species of this family.

Manuscript submitted 12 August 2020. Manuscript accepted 11 March 2021. Fish. Bull. 119:33-40 (2021). Online publication date: 8 April 2021. doi: 10.7755/FB.119.1.5

The views and opinions expressed or implied in this article are those of the author (or authors) and do not necessarily reflect the position of the National Marine Fisheries Service, NOAA.

\title{
The first data on the diet and reproduction of Fedorov's lumpsucker (Eumicrotremus fedorovi)
}

\author{
Ilya Gordeev (contact author) ${ }^{1,2}$ \\ Kristina Zhukova ${ }^{1}$ \\ Svetlana Frenkel ${ }^{1}$ \\ Email address for contact author: gordeev_ilya@bk.ru \\ ${ }^{1}$ Russian Federal Research Institute of Fisheries and Oceanography \\ 17 V. Kransnoselskaya Street \\ Moscow 107140, Russia \\ 2 Lomonosov Moscow State University \\ GSP-1 Leninskije Gory \\ Moscow 119991, Russia
}

The genus Eumicrotremus, 1 of 6 genera of Cyclopteridae (Scorpaeniformes: Cottoidei), includes 18 valid species (Froese and Pauly, 2020). This genus is distributed mostly in the northern Pacific Ocean. Four species inhabit subarctic and Arctic areas: pimpled lumpsucker (E. andriashevi), leatherfin lumpsucker (E. derjugini), Atlantic spiny lumpsucker (E. spinosus), and Newfoundland spiny lumpsucker (E. terraenovae). The Fedorov's lumpsucker (E. fedorovi) inhabits the waters of the northern Kuril Islands off the eastern coast of Russia (Mecklenburg and Sheiko, 2003) and has been rarely recorded as bycatch in the area of the Kuril Islands. Lumpsucker species spend most of their lives away from the shore. They can be found $100 \mathrm{~km}$ from shore in the open waters of the Pacific Ocean, before they return to shallow waters (200-300 m) to reproduce (Orlov, 1994; Chuchukalo, 2006).

No information on the diet of Fedorov's lumpsucker was available prior to this study. According to existing records on the diet of other Eumicrotremus species (Tabunkov and Chernysheva, 1985; Orlov, 1994; Melnikov, 1995; Kuznetsova, 1997; Chuchukalo et al., 1999; Roshchin, 2006; Antonenko et al., 2009; Berge and Nahrgang, 2013), lumpsucker species feed on various crustaceans, juveniles of squid species, pteropods, juveniles of fish species, and polychaetes. Lumpsucker species feed intensively throughout most of the year and have been reported to make diurnal vertical migrations in the water column to follow their main food item (hyperiids), and this movement pattern explains their regular presence in open water (Chuchukalo, 2006; Antonenko et al., 2009).

The reproductive biology of Cyclopteridae has been previously examined in studies of the lumpfish (Cyclopterus lumpus) and smooth lumpsucker (Aptocyclus ventricosus) (Cox and Anderson, 1922; Davenport, 1985; Kennedy, 2018; Zhukova et al., 2018). Information on the reproductive processes of other members of Cyclopteridae is scarce and fragmented. Lumpsucker species produce clusters of demersal adhesive eggs and spawn in coastal waters (at depths down to $300 \mathrm{~m}$ ). After spawning, males guard the fertilized eggs (Mecklenburg and Sheiko, 2003; Panchenko and Balanov, 2020). Female Pacific spiny lumpsucker (E. orbis) and spinous lumpfish (E. soldatovi) have been reported to have died after a single 
spawning, and males have been observed to guard egg clutches and then die when the eggs they were guarding complete development or hatch (Orlov, 1994). It is difficult, therefore, to determine if lumpsucker species feed during their entire life cycles. However, other representatives of Cyclopteridae, the Atlantic spiny lumpsucker, smooth lumpsucker, and lumpfish, can spawn several times during their life cycles (Cox and Anderson, 1922; Berge and Nahrgang, 2013; Zhukova et al., 2018).

In this paper, we provide the first comprehensive data on the stomach contents, gonadal development, and fecundity of Fedorov's lumpsucker and describe the biology and reproductive processes of this little known species.

\section{Materials and methods}

A total of 69 adult specimens of the Fedorov's lumpsucker were caught on the shelf and slope of Simushir Island, located near the center of the Kuril Islands in the Sea of Okhotsk in the northwest Pacific Ocean, from 19 March through 25 March 2017 during tows of the bottom trawl of the FV Anatoly Torchinov that targeted greenlings (Pleurogrammus spp.) at depths of 150-230 m. Specimens were caught near Simushir Island within the area bounded by the following coordinates: $46^{\circ} 46^{\prime} \mathrm{N}$ and $151^{\circ} 56^{\prime} \mathrm{E}, 46^{\circ} 40^{\prime} \mathrm{N}$ and $151^{\circ} 52^{\prime} \mathrm{E}$, and $46^{\circ} 44^{\prime} \mathrm{N}$ and $151^{\circ} 46^{\prime} \mathrm{E}$ (Fig. 1). All 69 specimens were frozen at $-20^{\circ} \mathrm{C}$ immediately after capture and then transported to the laboratory at the Russian Federal Research Institute of Fisheries and Oceanography in Moscow. The Fedorov's lumpsucker examined in this study ranged in total length (TL) from 64 to $103 \mathrm{~mm}$ and weighed from 12.4 to $64.0 \mathrm{~g}$. The 59 females caught were 64-103 $\mathrm{mm}$ TL (mean: $81.3 \mathrm{~mm}$ TL [standard deviation (SD) 1.23]) and 12.4-64.0 g (mean: $33.22 \mathrm{~g}$ [SD 1.36]), and the 10 males were $73-95 \mathrm{~mm}$ TL (mean: $84.7 \mathrm{~mm}$ TL [SD 2.50]) and 22.9-60.1 g (mean: $41.85 \mathrm{~g}$ [SD 5.00]).

After a specimen was thawed, the food items were collected from its stomach, separated under a MicroMed MC- $2^{1}$ stereomicroscope (CIT Nelian, Moscow, Russia), and weighed to the nearest milligram with analytical scales (R160P, Sartorius, Bohemia, New York). Fish specimens and food items were identified with the aid of Tuponogov and Kodolov (2014), Oku et al. (2017), and Voskoboinikova (2015).

Gonads of 14 females and 2 males (size: 64-92 mm TL and 30.1-38.5 g) were fixed in 10\% formalin, dehydrated, cleared with xylol, embedded in paraffin, sliced into sections $5 \mu \mathrm{m}$ thick, and stained with hematoxylin and Ehrlich's eosin. An Olympus BX45 microscope (Olympus

\footnotetext{
${ }^{1}$ Mention of trade names or commercial companies is for identification purposes only and does not imply endorsement by the National Marine Fisheries Service, NOAA.
}

Corp., Tokyo, Japan) equipped with a Leica DC 100 digital camera (Leica Microsystems, Buffalo Grove, IL) was used for imaging. Diameters of oocytes and intracellular structures were measured by using the software ImageJ, vers. 1.51 (Rasband, 2018).

The maturity phases of each ovary and testis were classified on the basis of the most advanced stage of germ cells observed in histological sections, according to the scale described by Guzmán et al. (2017). Ovaries were divided into 5 phases of development: onset of vitellogenesis, early vitellogenic, mid-vitellogenic, late vitellogenic, and periovulatory. Phase of testis maturity was determined on the basis of the presence or absence of male germ cells in a gonad: early recrudescence (spermatogonia and spermatocytes), mid-recrudescence (spermatogonia, spermatocytes, and spermatids), late recrudescence (spermatogonia, spermatocytes, spermatids, and spermatozoa), spermiating (spermatozoa prevail), and postspawning (spermatogonia and residual spermatozoa). Oocyte development was determinated by using the following stages and their associated indicators: primary growth (PG, absence of cortical alveoli and yolk granules), early developing (Vtg1, cortical alveoli and scattered yolk granules along the outer region of the cytoplasm), developing (Vtg2, yolk granules partly occupy the cytoplasm), fully vitellogenic (Vtg3, cytoplasm completely filled with yolk), and maturing ( $\mathrm{M}$, yolk globule fusion and nucleus migration).

Absolute and relative fecundity were estimated by using the gravimetric method (Murua and Saborido-Rey, 2003) for 5 frozen females (size: 74-95 mm TL and 25.4-60.1 g) 
at the late vitellogenetic and periovulatory macroscopic phases of gonadal maturity. A piece of ovarian tissue was taken from the median portion of the gonad from each specimen. The subsample of each ovary, representing $5-10 \%$ of the gonad weight, was weighed, and all advanced oocytes (1.7-2.3 $\mathrm{mm}$ in diameter) in the subsample were counted. The gonadosomatic index (GSI) and absolute $\left(F_{\text {abs }}\right)$ and relative $\left(F_{\text {rel }}\right)$ fecundity were estimated as follows:

$$
\begin{gathered}
G S I=(G W \times 100) / B W, \\
F_{\text {abs }}=(n \times G W) / w, \text { and } \\
F_{\text {rel }}=(n \times G W) /(w \times B W),
\end{gathered}
$$

where $n=$ the number of advanced oocytes in the subsample;

$w=$ the weight of the subsample (in grams);

$G W=$ the gonad weight (in grams); and

$B W=$ the body weight (in grams) of the specimen.

Standard deviations, Pearson's correlation coefficients $(r)$, Spearman rank correlation coefficients $(\rho)$, and $P$-values were calculated by using Microsoft Excel 2010 (Microsoft Corp., Redmond, WA) and statistical software R, vers. 3.6.3 (R Core Team, 2020).

\section{Results}

\section{Diet}

The stomachs of most of the specimens examined were full. The level of digestion in most cases made it possible to determine the species or taxon of food items. The weight of the boluses ranged from 9 to $3727 \mathrm{mg}$. Young walleye pollock (Gadus chalcogrammus), 36-61 mm TL; northern lampfish (Stenobrachius leucopsarus), 18-25 $\mathrm{mm}$ TL; and northern smoothtongue (Leuroglossus schmidti), 19-23 mm TL, as a group accounted for the majority of fish food items (Table 1). Walleye pollock were found in

\section{Table 1}

Frequency of occurrence and proportion of the total mass of food items found in the stomach contents of Fedorov's lumpsucker (Eumicrotremus fedorovi) caught during 19-25 March 2017 off Simushir Island, located near the center of the Kuril Islands in the northwest Pacific Ocean.

\begin{tabular}{lcc}
\hline Food item & $\begin{array}{c}\text { Occurrence } \\
\text { of food items } \\
(\%)\end{array}$ & $\begin{array}{c}\text { Mass } \\
\text { proportion } \\
(\%)\end{array}$ \\
\hline Gadus chalcogrammus & 69.57 & 40.55 \\
Hyperiida & 65.22 & 14.03 \\
Mysida & 62.32 & 26.44 \\
Calanoida & 52.17 & 3.98 \\
Gammarida & 44.93 & 3.86 \\
Stenobrachius leucopsarus & 40.58 & 9.93 \\
Leuroglossus schmidti & 2.90 & 0.65 \\
& & \\
\hline
\end{tabular}

almost $70 \%$ of stomachs and composed over $40 \%$ of the total weight of boluses collected from the specimens with food in their stomachs (65 of 69 specimens).

After walleye pollock, crustacean species were the most frequent food items (Table 1). Hyperiids were represented by only 2 species-Themisto pacifica and Primno macropa. Copepods were represented by several species of Calanoida, including Neocalanus cristatus, Gaetanus minutus, Paraeuchaeta elongata, Onchocalanus magnus, Pseudochirella obtusa, Cornucalanus indicus, Scaphocalanus sp., and Neocalanus spp. All calanoids were adults in the final development stage. Paraeuchaeta elongata was the most common copepod found in stomachs. Unfortunately, representatives of Mysidae lost most of their identifying characteristics when they were eaten by Fedorov's lumpsucker, and we could not identify them to the lowest taxon. Gammarids were represented by Cyphocaris challengeri (most commonly), Photis reinhardi, and a few specimens from the families Phoxocephalidae and Lysianassidae. In addition to the taxa given in Table 1 , there were several minor food items -2 specimens of Caprelloidea, both belonging to the family Caprellidae; a few small shrimp; the digested remains of fish from an unknown species; and a single squid, whose morphological features indicate that it is a specimen of either the Taonius belone or the Gonatopsis borealis.

\section{Reproduction}

Female Fedorov's lumpsucker have a pair of elongated ovaries attached to the dorsal wall of their body cavity. Ovaries at the phase of onset of vitellogenesis were small and flaccid, with no oocytes visible to the eye. Results of histological analysis indicate the presence of oocytes at the stage of PG, with some oocytes at the Vtg1 stage and oocytes sporadically at the Vtg2 stage (Fig. 2A). Oocytes at the PG stage had a mean diameter (Ø) of $128 \mu \mathrm{m}$ (SD 43) (Fig. 3), were ovoid, with basophilic cytoplasm and a large round nucleus in central position, and were found in all gonads (Fig. 4, A and D). Oocytes at the stage of Vtg1 had a mean $\varnothing$ of $325 \mu \mathrm{m}$ (SD 103) and were characterized by secondary growth at the beginning of vitellogenesis. Compared with that of the PG oocytes, the cytoplasm of the Vtg1 oocytes was more acidophilic with cortical alveoli, scattered yolk granules, and oil droplets (Fig. 4, A, B, and D).

Oocytes at the stage of Vtg2 had a mean $\varnothing$ of $533 \mu \mathrm{m}$ (SD 102), were characterized by cytoplasm partially filled with yolk, and were found in gonads in the mid- and late vitellogenic phases (Fig. 4, A, B, and D). Early vitellogenic gonads were bigger and less flaccid than ovaries at the onset of vitellogenesis and had scattered, visible small eggs with $\varnothing$ less than $1 \mathrm{~mm}$. Most germ cells were at the stages of PG and Vtg1, and Vtg2 germ cells were also found (Fig. 2B). Mid-vitellogenic ovaries were light orange in color, and oocytes were visible to the eye with $\emptyset$ of about $1 \mathrm{~mm}$. In such gonads, Vtg2 was the prevailing stage of oocytes (Fig. 2C). Late vitellogenic ovaries were dense and bright orange in color, and oocytes were clearly visible with $\varnothing$ from 1.0 to $1.6 \mathrm{~mm}$ (Fig. 2D). Most germ cells in 


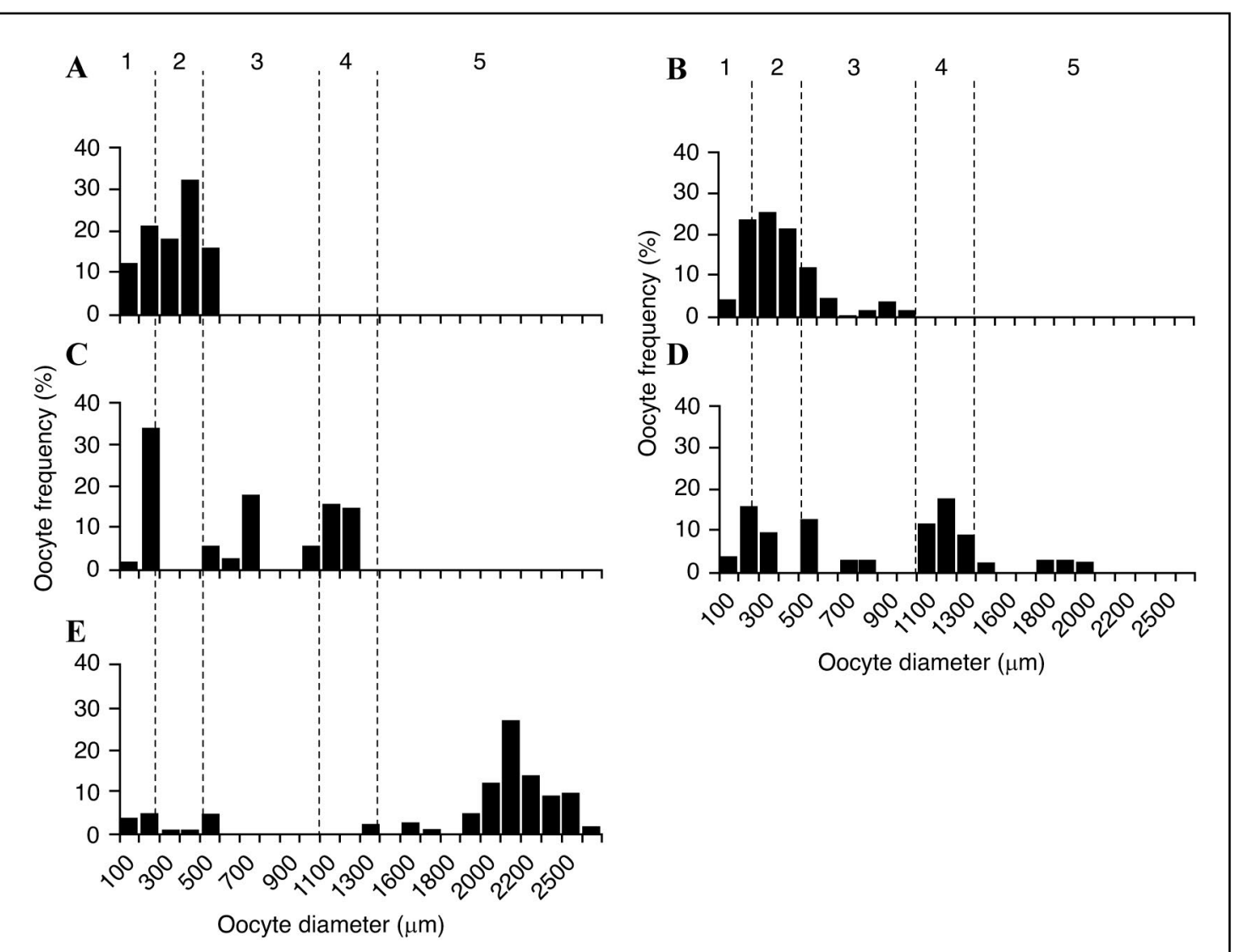

Figure 2

Frequency of occurrence of oocytes in Fedorov's lumpsucker (Eumicrotremus fedorovi) caught during 19-25 March 2017 off Simushir Island, by oocyte size and macroscopic phase of ovarian maturity: (A) onset of vitellogenesis, (B) early vitellogenesis, (C) mid-vitellogenesis, (D) late vitellogenesis, and (E) periovulatory. The vertical dashed lines indicate approximate boundaries between the sizes of oocytes at different histological stages of development: primary growth (1), early developing (2), developing (3), fully vitellogenic (4), and maturing (5).

such ovaries were at the Vtg3 stage. In Vtg3 oocytes, which had a mean $\varnothing$ of $1106 \mu \mathrm{m}$ (SD 83), the cytoplasm was completely filled with yolk globules (Fig. 4C). Periovulatory gonads were voluminous and contained oocytes with $\varnothing$ of about $2 \mathrm{~mm}$ and clearly visible oil droplets in germ cell cytoplasm. Most of the oocytes were at the $\mathrm{M}$ and $\mathrm{PG}$ stages (Fig. 2E). In M oocytes, which had a mean $\varnothing$ of $2036 \mu \mathrm{m}$ (SD 321), there were elongated masses of yolk globules with large oil droplets. Cytoplasm was surrounded by a zona radiata and a large chorion that was 28-30 $\mu \mathrm{m}$ thick (Fig. 4, D and E).

Absolute fecundity ranged from 297 eggs in the smallest female (size: $74 \mathrm{~mm}$ TL and $25.4 \mathrm{~g}$; GSI: 9\%) to 494 eggs in the largest female (size: $95 \mathrm{~mm}$ TL and $60.0 \mathrm{~g}$; GSI: $12 \%$ ), and mean $F_{\text {abs }}$ was 409 eggs (SD 87.9). Relative fecundity ranged from 7 to 12 eggs/gram of body weight, and mean $F_{\text {rel }}$ was 9 eggs/gram of body weight (SD 1.9). The only reliable correlation between body characteristics and fecundity is the negative correlation between body length and $F_{\text {rel }}(r=-0.92, P \leq 0.05 ; \rho=-0.97$, $P \leq 0.05 ; \mathrm{df}=3$ ). The correlations between body length and weight and $F_{\text {abs }}$ are generally positive but with low support $(P>0.05)$.

The testes of both males for which gonads were examined were classified as at the mid-recrudescence phase. The most advanced germ cells were spermatids; spermatogonia and spermatocytes were also present. Such composition of male germ cells indicates that active spermatogenesis was ongoing but that spermiogenesis had not yet begun. Germ cells were organized within cysts, surrounded by Sertoli cells and the interstitial compartment. The germinal compartment, consisting of male germ cells and Sertoli cells, was lobed, with spermatogonia distributed throughout the length of the lobes (Fig. 4F).

\section{Discussion}

The presence of benthic, benthopelagic, and pelagic species in guts of Fedorov's lumpsucker indicates that this species makes regular and significant vertical migrations; therefore, this species may be considered a 


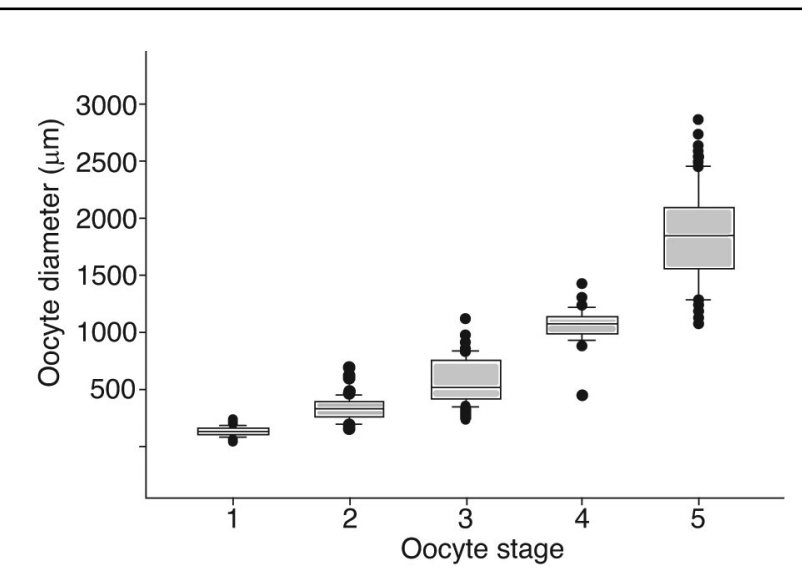

Figure 3

Box plot of the relationship between oocyte diameter and histological stages of maturity for Fedorov's lumpsucker (Eumicrotremus fedorovi) caught during 19-25 March 2017 around Simushir Island. The stages of oocyte development are primary growth (1), early developing (2), developing (3), fully vitellogenic (4), and maturing (5). The upper and lower parts of each box represent the first and third quartiles (the $25^{\text {th }}$ and 75 th percentiles), and the horizontal line is the median. The error bars indicate 1.5 times the interquartile range, and the black circles represent values outside this range.

eurybathic species, as has been reported previously for all lumpsucker species (Chuchukalo, 2006; Gordeev and Sokolov, 2020). All 3 fish species found in the stomach contents of Fedorov's lumpsucker-the walleye pollock, northern lampfish, and northern smoothtongue-are quite common in the area of and use the shelf of the Kuril Islands as breeding grounds. It is interesting that we did not find cumaceans or isopods in the stomach contents because they usually follow gammarids on the shelf (Neiman, 1988). Perhaps it is due to the feeding selectivity or the mosaic of bottom fauna.

A detailed analysis of food items allowed us to compare our results with the available data on the diet of congeners of the Fedorov's lumpsucker. According to Roshchin (2006), who studied the diet of Atlantic spiny lumpsucker in the Barents Sea, pelagic crustaceans of the family Hyperiidae, that is Themisto abyssorum and T. libellula, form the bulk of the food bolus of the Atlantic spiny lumpsucker. Benthic gammarids of the family Lysianassidae and a high Arctic species, Gammarus wilkitzkii, were also found. Northern shrimp (Pandalus borealis); a euphausiid, Thysanoessa inermis; and polychaetes of the genus Nereis were found in only a few of the examined lumpsucker. Berge and Nahrgang (2013) stated that there was a similar pattern of Atlantic spiny lumpsucker feeding on Themisto libellula in the environs of Spitzbergen, an island in the Svalbard archipelago in Norway. They also noted chaetognaths in boluses. The Pacific Ocean representative, Pacific spiny lumpsucker, studied in the Gulf of Patience off the eastern coast of Sakhalin Island in Russia, feeds mainly on hyperiids, euphausiids, and decapod larvae (Tabunkov and Chernysheva, 1985).

The most recent study on the diet of a lumpsucker species (Antonenko et al., 2009) stated that the Siberian lumpsucker (E. asperrimus) feeds almost entirely on the hyperiid T. japonica in the waters of the Primorsky Krai (Maritime Territory) of Russia. Primno macropa and euphausiids of the genus Thysanoessa were rarely found. According to Chuchukalo et al. (1999), E. tartaricus feeds equally on both planktonic hyperiids and on young boreopacific armhook squid (Gonatopsis borealis) in the northern part of the Sea of Okhotsk. Spinous lumpfish studied in the Sea of Okhotsk fed mostly on hyperiids, such as Themisto japonica and T. libellula, and on euphausiids, including Thysanoessa raschii and Thysanoessa sp.; juvenile squid, pteropods, mysids, polychaetes, gammarids, and juvenile fish were only occasionally found (Orlov, 1994; Melnikov, 1995; Kuznetsova, 1997). There is also a record that, in 1993, spinous lumpfish fed mainly on isopods and the ctenophore Beroe sp. (Kuznetsova, 1997). Northern smoothtongue and leatherfin lumpsucker have feeding habits quite similar to that of the Pacific spiny lumpsucker (Chuchukalo, 2006).

Therefore, Fedorov's lumpsucker, similarly to other studied species of Eumicrotremus, feeds on actively moving crustaceans. However, the diet of Fedorov's lumpsucker is differentiated from that of other studied congeneric species by the large proportions by mass of the diet that are fish and mysids $(51.10 \%$ and $26.44 \%$, respectively; Table 1). Chuchukalo (2006) wrote that the narrow food specialization (on hyperiids and euphausiids) of most lumpsucker species is not typical for planktoneating species of fish and is probably attributable to the similarity of behavior, morphological features, and close ecology of these species. Our research revealed that the diet of the Fedorov's lumpsucker could include almost any benthopelagic animal; therefore, the genus Eumicrotremus could be labeled as euryphagous. Because the majority of the food items found in specimens stomachs in this study were in good condition, it can be presumed that food was sucked into the mouths of individuals with a stream of water that resulted from a sharp increase in the volume of the buccal cavity.

Size-frequency analyses of oocytes revealed discontinuous oogenesis (determinate fecundity), group-synchronous ovarian organization (release of eggs once in the spawning season), and total spawning, following the classification of Murua and Saborido-Rey (2003). Similar reproductive strategies have been recorded for other representatives of Cyclopteridae, such as the smooth lumpsucker (Zhukova et al., 2018).

Semelparous species have very low or exhausted reserves of $\mathrm{PG}$ oocytes in prespawning gonads (Mouchlianitis et al., 2019). The presence of quite a lot of PG oocytes in all examined ovaries and of primary spermatogonia in testes examined in our study confirms that the Fedorov's lumpsucker is an iteroparous species.

The chorion and thick zona radiata present in ovaries of Fedorov's lumpsucker correspond to the condition of eggs in 


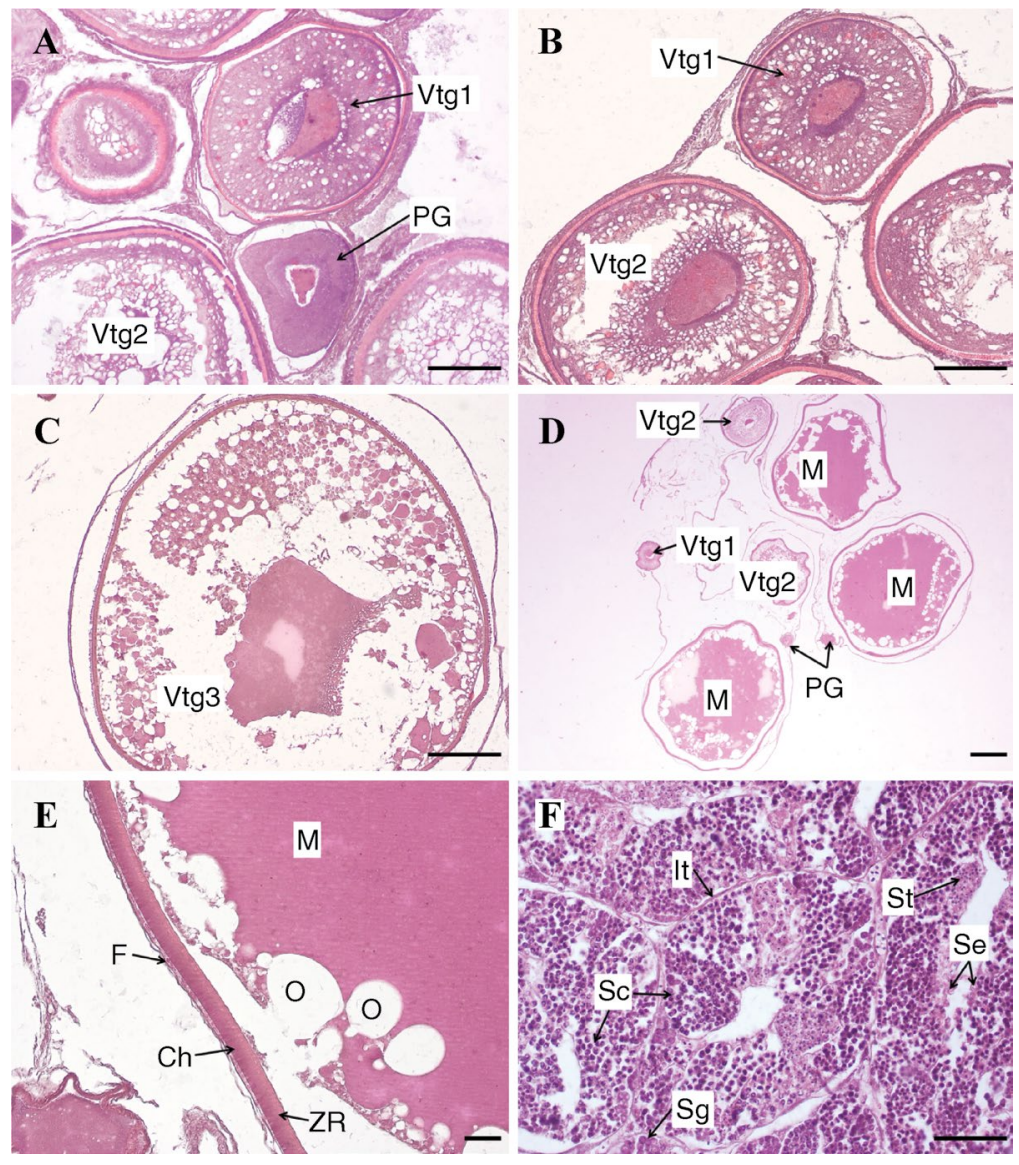

Figure 4

Images of gonads of Fedorov's lumpsucker (Eumicrotremus fedorovi), caught during 19-25 March 2017 around Simushir Island, at various macroscropic phases of development: $(\mathbf{A})$ early vitellogenesis, $(\mathbf{B})$ mid-vitellogenesis, $(\mathbf{C})$ late vitellogenesis, and $(\mathbf{D}, \mathbf{E})$ periovulatory ovaries and $(\mathbf{F})$ a mid-recrudescence testis. The histological stages, structures of germ cells, and gonadal elements are indicated in the images as follows: primary growth (PG), early developing (Vtg1), developing (Vtg2), fully vitellogenic (Vtg3), and maturing (M) oocytes, as well as oil droplets $(\mathrm{O})$, zona radiata $(\mathrm{ZR})$, chorion $(\mathrm{Ch})$, follicular layer $(\mathrm{F})$, spermatogonia (Sg), spermatocytes (Sc), spermatids (St), Sertoli cells (Se), and interstitial tissue (It). The lengths of the scale bars represent $100 \mu \mathrm{m}$ (panels A, $\mathrm{B}$, and E), $200 \mu \mathrm{m}$ (panel C), $500 \mu \mathrm{m}$ (panel D), and $50 \mu \mathrm{m}$ (panel F).

The $F_{\text {abs }}$ of the Fedorov's lumpsucker in our study was significantly lower than that reported for other species of Cyclopteridae. For example, in another study, fecundity of lumpfish ranged from 50,000 to 159,000 eggs (Gregory and Daborn, 1982). The values of $F_{\text {abs }}$ of Atlantic spiny lumpsucker and smooth lumpsucker have been reported to be more than 1000 eggs (Dolgov ${ }^{2}$; Hutchings ${ }^{3}$ ) and between 24,240 and 63,756 eggs (Zhukova et al., 2018), respectively. Such low values of $F_{\text {abs }}$ and low GSI values are due to the smaller body size of Fedorov's lumpsucker (size: 74-95 mm TL; GSI: 9-12\%) compared with the size of lumpfish (size: $370-450 \mathrm{~mm}$ TL; mean GSI: $18 \%$ [SD 5.8]) and of smooth lumpsucker (size: 170-350 mm TL; GSI: 31-56\%) (Zhukova et al., 2018). Among close relatives of the Fedorov's lumpsucker, only the Atlantic spiny lumpsucker had lower GSI values in prespawning females with similar body length (77.30 mm [SD 15.80]), with GSI values of $4.5 \%$ according to Hutchings ${ }^{3}$ or $1.4-4.8 \%$ according to Berge and Nahrgang (2013). This circumstance is in line with the very weak positive correlation (linear regression: coefficient of multiple determination=0.31) between total weight and the GSI, indicating equal gonadal development between each size class (Berge and Nahrgang, 2013). The $F_{\text {rel }}$ was 2 times lower in Fedorov's lumpsucker than in smooth lumpsucker (Zhukova et al., 2018). In both species, $F_{\text {rel }}$ is also associated with the size of females.

The structure of the testes and distribution of spermatogonia for the males examined in our study indicate that male gonads were of the unrestricted lobular testis type, as defined by Uribe et al. (2014). Similar testis types have been recorded for lumpfish (Guercini, 2019) and for other teleost species of Percidae, Centropomidae,

specimens of other fish species that are releasing demersal eggs. Adhesive and demersal eggs have been reported for other species of Cyclopteridae (Washington et al., 1984) and for representatives of the families Liparidae, Osmeridae, Salmonidae, Pleuronectidae, and Clupeidae (Able and Musick, 1976; Stehr and Hawkes, 1979).

The sizes of germ cells at different stages of development found in our study were comparable to those reported for the smooth lumpsucker (Zhukova et al., 2018). The diameters of oocytes at the $M$ stage were the same as those in lumpfish and a little smaller than those in Atlantic spiny lumpsucker and Siberian lumpsucker (Wienerroither et al., 2011; Panchenko and Balanov, 2020).
Rachycentridae, Cichlidae, Gadidae, Synbranchidae, and Erythrinidae (Grier et al., 1980; Taylor et al., 1998; Brown-Peterson et al., 2002; Lo Nostro et al., 2003; Bizzotto and Godinho, 2007). Therefore, the results of our study provide the first data on the diet and reproductive features for the rarely caught Fedorov's lumpsucker.

\footnotetext{
${ }^{2}$ Dolgov, A. V. 1994. Some aspects of biology of non-target fish species in the Barents Sea. ICES CM 1994/O:12, 23 p. [Available from website.]

${ }^{3}$ Hutchings, J. A. 2002. Ecology and biodiversity of commercially unexploited marine fishes in the Northwest Atlantic, 14 p. Final report. Dalhousie Univ., Halifax, Canada.
} 


\section{Acknowledgments}

We wish to thank the crew of the FV Anatoly Torchinov (Primorskaya Rybolovnaya Co. Ltd.) for help with sampling, O. Voskoboinikova (Zoological Institute, Russian Academy of Sciences [RAS], St. Petersburg) for help with fish identification, A. Basin (Shirshov Institute of Oceanology, RAS, Moscow) for the identification of gammarids, V. Napazakov (Pacific Branch of Russian Federal Research Institute of Fisheries and Oceanography, Vladivostok) for the identification of hyperiids, and F. Lishchenko (Severtsov Institute of Ecology and Evolution, RAS, Moscow) for the identification of the squid.

\section{Literature cited}

Able, K. W., and J. A. Musick.

1976. Life history, ecology, and behavior of Liparis inquilinus (Pisces: Cyclopteridae) associated with sea scallop, Placopecten magellanicus. Fish. Bull. 74:409-421.

Antonenko, D. V., O. I. Pushchina, and S. F. Solomatov.

2009. Seasonal distribution and some features of the biology of spiny lumpfish Eumicrotremus asperrimus (Cyclopteridae, Scorpaeniformes) in the northwestern part of the Sea of Japan. J. Ichthyol. 47:674. Crossref

Berge, J., and J. Nahrgang.

2013. The Atlantic spiny lumpsucker Eumicrotremus spinosus: life history traits and the seemingly unlikely interaction with the pelagic amphipod Themisto libellula. Pol. Polar Res. 34:279-287.

Bizzotto, P. M., and H. P. Godinho.

2007. Morphometric evaluation of the spermatogenesis in trahira Hoplias malabaricus (Bloch) (Characiformes, Erythrinidae). Rev. Bras. Zool. 24:541-544. Crossref

Brown-Peterson, N. J., H. J. Grier, and R. M. Overstreet. 2002. Annual changes in the germinal epithelium determine male reproductive classes of the cobia. J. Fish Biol. 60:178-202. Crossref

Chuchukalo, V. I.

2006. Feeding and feeding relations of nekton and nektobenthos in Far Eastern Seas, 484 p. Tikhookean. Nauchno-Issled. Rybokhoz. Tsentr (TINRO), Vladivostok, Russia. [In Russian.]

Chuchukalo, V. I., V. V. Lapko, N. A. Kuznetsova, A. M. Slabinsky,

V. V. Napazakov, V. F. Nadtochiy, V. N. Koblikov, and

O. I. Pushchina.

1999. Feeding of bottom fish on the shelf and the continental slope of the northern part of the Sea of Okhotsk in summer 1997. Izv. Tikhookean. Nauchno-Issled. Rybokhoz. Tsentra (TINRO) 126:24-57. [In Russian.]

Cox, P., and M. Anderson.

1922. No. 1: a study of the lumpfish (Cyclopterus lumpus L.). Contrib. Can. Biol. Fish. 1:1-20. Crossref

Davenport, J.

1985. Synopsis of biological data on the lumpsucker, Cyclopterus lumpus (Linnaeus, 1758). FAO Fish. Synop. 147, 31 p. FAO, Rome.

Froese, R., and D. Pauly (eds.). 2020. FishBase. World wide web electronic publication, vers. 12/2020. [Available from website, accessed February 2021].

Gordeev, I. I., and S. G. Sokolov.

2020. Macroparasites of epipelagic and eurybathic fishes in the north-western Pacific. Invertebr. Zool. 17:118-132. Crossref
Gregory, R. S., and G. R. Daborn.

1982. Notes on adult lumpfish Cyclopterus lumpus L. from the Bay of Fundy. Proc. N.S. Inst. Sci. 32:321-326.

Grier, H. J., J. R. Linton, J. F. Leatherland, and V. L. De Vlaming. 1980. Structural evidence for two difference testicular types in teleost fishes. Am. J. Anat. 159:331-345. Crossref

Guercini, E.

2019. Effects of light and temperature regimes on the sexual maturation of male lumpfish (Cyclopterus lumpus). M.S. thesis, 37 p. Nor. Univ. Sci. Technol., Trondheim, Norway. [Available from website.]

Guzmán, J. M., J. A. Luckenbach, M. A. Middleton, K. C. Massee, C. Jensen, F. W. Goetz, A. J. Jasonowicz, and P. Swanson.

2017. Reproductive life history of sablefish (Anoplopoma fimbria) from the U.S. Washington coast. PLoS ONE 12(9):e0184413. Crossref

Kennedy, J.

2018. Oocyte size distribution reveals ovary development strategy, number and relative size of egg batches in lumpfsh (Cyclopterus lumpus). Polar Biol. 41:1091-1103. Crossref

Kuznetsova, N. A.

1997. Feeding of some plankton-eating fish in the Sea of Okhotsk during the summer period. Izv. Tikhookean. Nauchno-Issled. Rybokhoz. Tsentr (TINRO) 122:255-275. [In Russian.]

Lo Nostro, F., H. Grier, L. Andreone, and G. A. Guerrero.

2003. Involvement of the gonadal germinal epithelium during sex reversal and seasonal testicular cycling in the protogynous swamp eel, Synbranchus marmoratus Bloch 1795 (Teleostei, Synbranchidae). J. Morphol. 257:107-126. Crossref

Mecklenburg, C. W., and B. A. Sheiko.

2003. Family Cyclopteridae Bonaparte 1831-lumpsuckers. Calif. Acad. Sci., Annotated Checkl. Fishes 6, 17 p. [Available from website.]

Melnikov, I. V.

1995. Distribution and some features of Soldatov's lumpsucker Eumicrotremus soldatovi biology in the Sea of Okhotsk. J. Ichthyol. 35:433-439. [In Russian.]

Mouchlianitis, F. A., A. F. Belo, A. R. Vieira, B. R. Quintella, P. R. Almeida, and K. Ganias.

2019. Primary and secondary oocyte growth dynamics in anadromous semelparous Allis shad Alosa alosa. J. Fish Biol. 95:1447-1456. Crossref

Murua, H., and F. Saborido-Rey.

2003. Female reproductive strategies of marine fish species of the North Atlantic. J. Northwest Atl. Fish. Sci. 33:23-31. Crossref

Neiman, A. A.

1988. Quantitative distribution and trophic structure of the benthic shelf of the World Ocean, 101 p. VNIRO Publ. House, Moscow, Russia. [In Russian.]

Oku, K., H. Imamura, and M. Yabe.

2017. Phylogenetic relationships and a new classification of the family Cyclopteridae (Perciformes: Cottoidei). Zootaxa 4221:1-59. Crossref

Orlov, A. M.

1994. Some characteristics of distribution and biological status of Eumicrotremus soldatovi (Cyclopteridae) in the northeastern part of the Sea of Okhotsk during the spring. J. Ichthyol. 34:122-127.

Panchenko, V. V., and A. A. Balanov.

2020. The distribution of adult males of the Siberian lumpsucker Eumicrotremus asperrimus (Tanaka, 1912) (Cyclopteridae) off the northern Primorsky Krai Coast, Sea of Japan, and remarks on the reproduction of this species. Russ. J. Mar. Biol. 46:81-87. Crossref 
$\mathrm{R}$ Core Team.

2020. R: a language and environment for statistical computing. R Foundation for Statistical Computing, Vienna, Austria. [Available from website, accessed August 2020.]

Rasband, W. S.

2018. ImageJ. U.S. Natl. Inst. Health, Bethesda, MD [Available from website.]

Roshchin, E. A.

2006. New data on morphometry, feeding, and parasitic fauna of Atlantic spiny lumpsucker Eumicrotremus spinosus (Cyclopteridae) from the Barents Sea. J. Ichthyol. 46:582-586. Crossref

Stehr, C. M., and J. W. Hawkes.

1979. The comparative ultrastructure of the egg membrane and associated pore structures in the starry flounder, Platichthys stellatus (Pallas), and pink salmon, Oncorhynchus gorbuscha (Walbaum). Cell Tissue Res. 202:347-356. Crossref

Tabunkov, V. D., and E. R. Chernysheva.

1985. Feeding non-target fish species in the Gulf of Patience. Izv. Tikhookean. Nauchno-Issled. Rybokhoz. Tsentr (TINRO) 110:98-104. [In Russian.]

Taylor, R. G., H. J. Grier, and J. A. Whittington.

1998. Spawning rhythms of common snook in Florida. J. Fish Biol. 53:502-520. Crossref

Tuponogov, V. N., and L. S. Kodolov.

2014. Field guide for commercial and common species of fish of the Far Eastern Seas of Russia, 336 p. Russkiy Ostrov Publ., Vladivostok, Russia. [In Russian.]
Uribe, M. C., H. J. Grier, and V. Mejía-Roa.

2014. Comparative testicular structure and spermatogenesis in bony fishes. Spermatogenesis 4(3):e983400. Crossref

Voskoboinikova, O. S.

2015. New genus of the family Cyclopteridae-Microancathus gen. n. (Pisces: Cottoidei: Cyclopteridae) with description of a new species Microancathus tokranovi sp. n. Tr. Zool. Inst. RAN 319(2):215-228. [In Russian.]

Washington, B. B., H. G. Moser, W. A. Laroche, and W. J. Richards. 1984. Scorpaeniformes: development. In Ontogeny and systematics of fishes (H. G. Moser, J. Richards, D. M. Cohen, M. P. Fahay, A.W. Kendall, and S. L. Richards, eds.), p. 405-428. Am. Soc. Ichthyol. Herpetol., Spec. Publ. 1. Allen Press, Lawrence, KS.

Wienerroither, R., Johannesen, E., Dolgov, A., Byrkjedal, I. Bjelland, O, Drevetnyak, K., Eriksen, K. B., Høines, Å., Langhelle, G., Langøy, et al.

2011. Atlas of the Barents Sea fishes. IMR/PINRO Joint Rep. Ser. 1-2011, 272 p. [Available from website.]

Zhukova, K., O. A. Maznikova, and A. M. Orlov.

2018. Gonadal maturation of the female smooth lumpsucker (Aptocyclus ventricosus). Fish. Bull. 116:153-160. Crossref 